\author{
(online) = ISSN $2285-3642$ \\ ISSN-L = $2285-3642$ \\ Journal of Economic Development, Environment and People \\ Volume 2, Issue 3, 2013 \\ URL: http://jedep.spiruharet.ro \\ e-mail: office jedep@spiruharet.ro
}

\title{
New Bangalores? The role of Central and Eastern Europe in business and IT services offshoring
}

\author{
Zoltán Gál, Ph.D. senior research fellow, \\ Centre for Economic \& Regional Studies, Hungarian Academy of Sciences \\ Associate professor, University of Kaposvár, Faculty of Economics \\ E-mail: galz@rkk.hu
}

\begin{abstract}
.
The paper discusses how the second global shift in business services provision and corporate restructuring open up new offshoring opportunities into Central and Eastern Europe (CEE). It explores three issues: First, it builds upon the theoretical framework of the 'new paradigm of globalization, which considers offshoring as one of the most important globalizing forces of recent time. This results in a shift in global trade, namely from 'trade in goods' to 'trade in tasks' determined by the changing trends in the division of labour. Second, the paper gives an overview of services relocation into CEE in comparison with its Asian counterparts. As the EU expanded eastwards, the opportunities for European corporations to offshore their business services to these 'nearshore' locations increased. Building on the region's nearshoring advantages such as geographical-cultural proximity and on their multilingual graduate supply, CEE is likely to utilise more value added quality-driven BPO and KPO services. Third, the paper examines the implications of offshoring for the home markets in CEE assessing its impact on their locations. It reveals the role of offshoring activities in the metropolitan transformation and discusses the factors that make the capital cities an increasingly attractive option for companies to relocate their services. Despite CEE has taken advantage on the trend supported by the global service delivery models reducing dependency on any single location, its further growth may be influenced by the worsening macro-conditions, and future prospect of the region depends largely on government incentives and on the success of exploiting talent pools offered by its provincial cities.
\end{abstract}

Keywords: second global shift, trade in tasks, offshoring, corporate location strategies, 'nearshoring', Central and Eastern Europe, primary and secondary offshoring locations.

JEL Codes: F21, F23, J 21, L8, R12 


\author{
(online) = ISSN $2285-3642$ \\ ISSN-L = 2285-3642 \\ Journal of Economic Development, Environment and People \\ Volume 2, Issue 3, 2013 \\ URL: $\underline{\text { http://jedep.spiruharet.ro }}$ \\ e-mail: office jedep@spiruharet.ro
}

\title{
1. Introduction
}

The key feature of the second global shift is the offshoring (relocation or global sourcing) $)^{1}$ of a range of service functions from the USA and Europe to low cost developing countries. Improvements in communication technology helping companies in moving services across country borders has dramatically increased the ability of companies to source production anywhere in the world. The dropping relative prices of services, especially those found in the ICT sectors together with the recent liberalisation of trade is facilitating the spatial fragmentation of value chains alongside the services functions. Offshoring is regarded in the literature as one of the most important globalisation forces. Thomas Friedman in his latest book, The World is Flat (2005), describes offshoring among the major "flatteners" of the technological, economic and social shifts that effectively leveled the economic world, and "accidentally made Beijing, Bangalore and Bethesda next-door neighbours". A global, Internet-enabled platform for various forms of sharing knowledge and tasks in services, irrespective of time, distance, geography and increasingly, language has created the flat World. Nevertheless, the world remains far from flat and proximity, geographical factors still matter a great deal for many service tasks, because their exchange requires face-to-face proximity between partners.

Transportation and communication costs, as well as geographic proximity to customers, workers and suppliers have become less important for many service tasks. The rapid surge of globalisation, opening up of formerly isolated regions such as Eastern Europe, Russia and China to global trade, has substantially boosted task trade and service related cross-border investment. Many Eastern European countries invigorated by the EU enlargement became important locations for services to be offshored. The question is whether these locations might stand as a challenge for the overwhelmingly dominant global position of India and the other East Asian countries or only offer complementary offshoring base for the continental European companies preferring relocating their services nearby. There is a large amount of anecdotal information underpinned by the recent estimates of consultants' reports, which are viewing CEE as an attractive region for offshoring even in global context. Its leading cities are now seen by some analysts as "future Bangalores" in terms of providing offshoring solutions.

This paper attempts to confirm the recent anecdotal evidence by means of using trade and specific location sites data in order to overcome the scarcity of consistent empirical contributions to measure the

\footnotetext{
${ }^{1}$ Offshoring and outsourcing often used as an interchangeable phenomenon. While outsourcing is delegating an internal business process to an external company, offshoring means the geographical spread and decentralization of production of exchange through the relocation of activities from one site to another. Although, offshoring can occur in combination with outsourcing, but this need not be the case
} 


\author{
(online) = ISSN $2285-3642$ \\ ISSN-L = 2285-3642 \\ Journal of Economic Development, Environment and People \\ Volume 2, Issue 3, 2013 \\ URL: $\underline{\text { http://jedep.spiruharet.ro }}$ \\ e-mail: office jedep@spiruharet.ro
}

actual significance of CEE in services offshoring. Research on this topic is limited by the lack of appropriate data and the available data can be used to define offshoring only with certain restriction. For instance, FDI data can be indecisive because the cost of services investment (e.g. set up an shared services centre), just like the invested amount is minimal. The employment figure by offshoring projects, if they were available, would allow international comparison. The service export data adopted from the Balance of Payment statistics gives a good approximation to identify those sections in service trade which can be regarded as offshorable.

The paper is divided into five sections. Following the introduction, the second section puts offshoring into the wider context of the economic literature in order to prove that outsourcing and relocation processes not only restructuring the organisational base and geographical accessibility of firms but also it can be interpreted as the key factor constituting the latest phase of globalization. The third section gives an overview of international market of offshoring services. The fourth explores the reasons behind the growing popularity of CEE as an offshoring hub and examines the service trade trends and the comparative advantages of the East European region. The last section examines the home market effects and the impact of offshoring on the local urban network, while the conclusion discusses the sustainability of the region's attractiveness and comparative advantages.

\title{
2. Offshoring as a new paradigm of globalization
}

The fragmentation of production processes across distances, national borders - like globalization - is not an entirely new phenomenon but advances in ICT have accelerated this trend and enabled inroads to the tradable and commoditized services. ${ }^{2}$ It goes along with the growing internationalization and large scale spatial dispersion of production and service networks. Service sector outsourcing and offshoring are geographically determined processes of the contemporary global production system as they create dynamic spatial interactions between different - notably the global, the regional, the national and the local - geographical scales (Jones, Kierzkowski, 1990).

However, these production processes have not always been so flexible and 'footloose' in terms of the spatial levels of their operation. Service sector such as manufacturing before was mostly exempt from spatial and organizational fragmentation in the past. Economic activities during the various stages of the two centuries long modernization process produced much differentiated geographies (see Table 1). The

\footnotetext{
${ }^{2}$ Offshoring reflects the tradability revolution of services. Traditionally, most services were non-tradable and it had even stronger proximity requirement regarding to the geographical position of sellers and buyers. The original precondition of tradability is the use of ICT which allows knowledge to be standardized and digitized, allowing more and more services to fragment their different tasks into smaller components that can be located elsewhere to take the cost, quality and scale economies advantages of the particular location.
} 


\author{
(online) $=$ ISSN $2285-3642$ \\ ISSN-L = 2285-3642 \\ Journal of Economic Development, Environment and People \\ Volume 2, Issue 3, 2013 \\ URL: $\underline{\text { http://jedep.spiruharet.ro }}$ \\ e-mail: office jedep@spiruharet.ro
}

interaction between organizational and geographical dimensions of national/international/transnational production networks created complex structures in which elements of both concentration and dispersal are apparent. The importance of these processes can be not only different in each stages of modernization but requires different kind of embeddings (Grossman and Rossi-Hansberg, 2007).

In the age of Adam Smith, transportation was costly and therefore the fragmentation of production activities in remote locations was difficult and uneconomical. For the subsequent two centuries, the still higher cost of moving goods dictated agglomeration in production, resulting in the geographic clustering of production and people, although it did not necessitate performing production close to the consumption.

The economic geography of that time as Grossman and Rossi-Hansberg (2008) argue was characterized by agglomeration in production rather than fragmentation and specialization required geographic concentration. Countries specialized in making goods from start to finish participate in the world economy with the exchange of different complete goods and fostered the rapid expansion of international trade. This period was characterized by the rapid industrial concentration in the North and southern deindustrialization (Baldwin, 2006).

In the last three decades as the rapidly decreasing communication and coordination costs have fostered the end of the need to perform most manufacturing stages near to each other. The lower cost of transport and information generated a rapid industrialization in the South. The emergence of Southern industrialization forces a relative deindustrialization in the North resulting in a steady shift to services away from industry and parallel geographical separation of various production stages became more attractive. TNCs in the North started to offshore almost all labour intensive stages of production to low cost developing countries creating a transnational network of affiliates. This was the first global shift is associated with relocation of manufacturing employment to low-cost production sites (Baldwin, 2006). As communication technologies have weakened the link between specialization and geographic concentration (specialization needs no geographic concentration), the separation of tasks in time and space became possible. This second shift of globalization 'spatially unpacked' the factories and offices from each other and concentrated into the services sector. The relocation of mostly routine tasks, functions rather than sectors became more common. New "trade in task" paradigm shown in Figure 1 developed by Grossman and Rossi-Hansberg (2008) called this process fragmentation. Advances in this process have made it easier for companies to disaggregate their value chains around the globe, all the while maintaining management control over them, or to disperse service production among numerous supplier firms even in distant locations, contrary to the earlier stages of globalization when specialization required geographic concentration and agglomeration forces were prevailing (Baldwin, 2006; Baldwin and Krugman, 2004). 
(online) = ISSN $2285-3642$

ISSN-L = 2285 - 3642

Journal of Economic Development, Environment and People

Volume 2, Issue 3, 2013

URL: $\underline{\text { http://jedep.spiruharet.ro }}$

e-mail: office jedep@spiruharet.ro

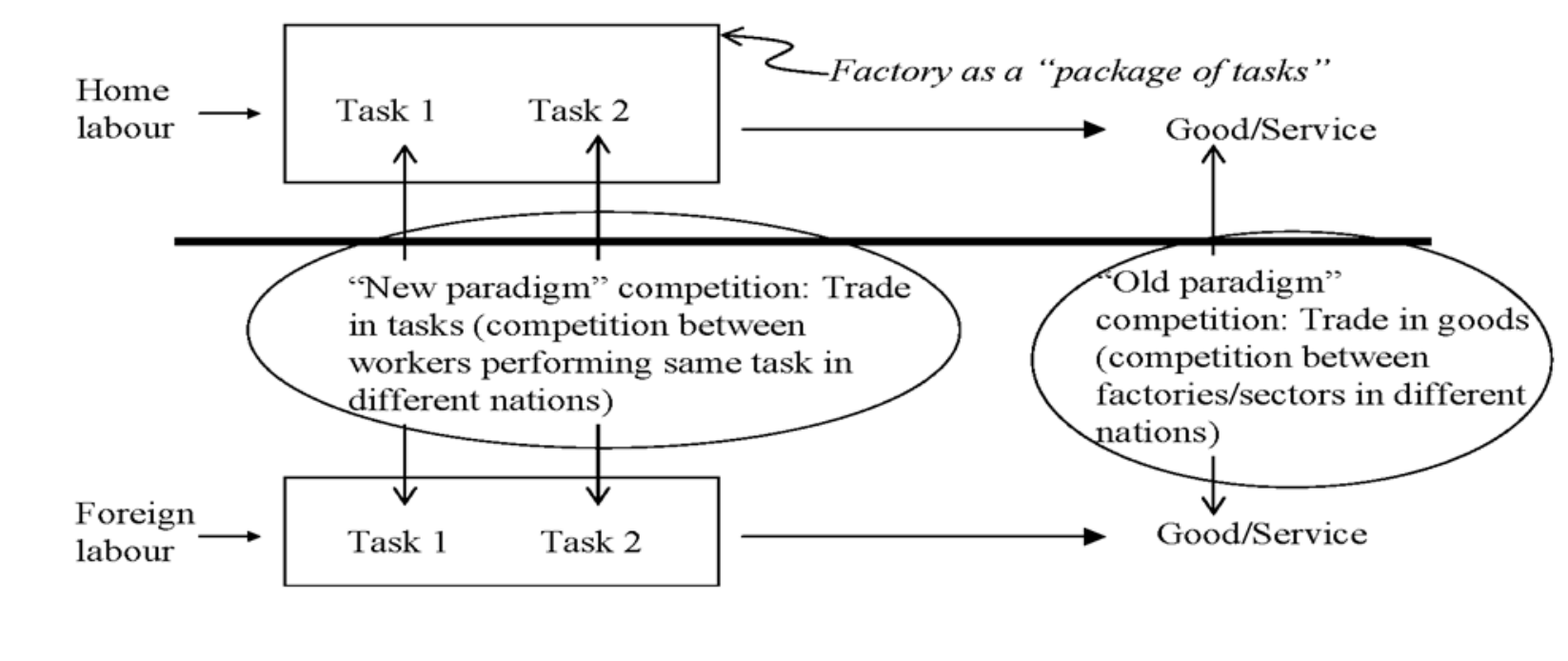

Fig. 1: Task trade: Grossman and Rossi -Hansberg theorem (Source: Baldwin (2006))

Offshoring became a key globalization force and one can argue it is the latest phase of globalization, which has been challenging the traditional territorial division of labour (Blinder, 2006):

The new economic geography (NEG), focusing on the spatial concentration of economic activities has been challenged by the global fragmentation, a geographical spread and decentralization of services activities. Changes in organization and IT reduced the difficulties of coordinating services from distance by enabling firms more easily fragment their production stages (value chains). The fragmentation requires infrastructure and service production capacity in distant places, foreign direct investment can be facilitated the process of decentralization. It means a relocation to host country all or part of service production as the companies can benefit from the various alternative locations endowed with specific local resource based advantages. Some service activities are not fixed in space and can be provided either as a form of foreign trade or by the temporary relocation of a service worker to a client's premises. Other specialist services can be provided only from central locations.

Today neither the comparative advantage nor the traditional NEG approaches are seem to be adequate to explain the territorial dimension of fragmentation. Service value chains became increasingly offshorable not just within but also across regional economies, which opened up a new territorially embedded systems of core service functions challenging obsolete Marshallian districts and clusters by their dispersed global networks. Fragmentation is not simply spatial dispersion in a certain sense but 


\author{
(online) = ISSN $2285-3642$ \\ ISSN-L = $2285-3642$ \\ Journal of Economic Development, Environment and People \\ Volume 2, Issue 3, 2013 \\ URL: $\underline{\text { http://jedep.spiruharet.ro }}$ \\ e-mail: office jedep@spiruharet.ro
}

fragmentation means that external linkages interpenetrate the territorially embedded value chains not only in manufacturing but in services, diminishing the home bias even for the core service operation (Grossman and Rossi-Hansberg 2008; Baldwin 2006).Outsourcing and offshoring are both regarded as means to reduce costs and also can be seen as the expression of corporate strategies to distribute risks across a number of service providers and different locations. However, offshoring and outsourcing may be associated with a different landscape wherein the former reinforce local-regional growth and the latter reinforce productive efficacy of the global network at the expense of local economic prosperity. In this sense, offshoring is more consistent with the NEG supporting regional economic growth, while outsourcing relying on extensive inter-regional growth challenges the NEG, and, 'in particular the claimed the necessity that networks of production and exchanges need to be local to create value between network partners' (Clark and Freeman, 2008).

The reason behind the creation of global value chains during the stages of the first and the second global shift also differ from each other (see Table 1). Along with the stages of development associated with the global shifts the nature of FDI has also changed. Traditionally investments seek access to natural resources, production and market building, while recently services increased their share within FDI (Dicken 2003). As argued by Metters and Verma (2008) offshoring is not a new phenomenon as it has been applied to the relocation of isolated stages of labour intensive manufacturing to low-wage developing countries in the form of vertical direct investment during the first global shift. What is new now is its application to knowledge intensive business and financial services. However, recently horizontal investment gains importance as strong flows of FDI across countries are motivated not only by low cost benefits but also by the avoidance of exchange risks, quality labour, and by the quest for proximity advantages with a direct local presence (Bräuninger 2007). Global service providers can locate their units to take advantage of geographical variation of production costs at global scale. In other words, transnational vertical specialisation and integration became feasible, in which different tasks of a service firm's value chain are located in the different parts of the world (Bryson, 2007).

Offshoring has a strong impact on deciding what kind of jobs are being offshored and what are the main differentiating factors from the earlier wave of relocations? While earlier mainly blue-collar jobs were offshorable recently a variety of skill-intensive and cross-sectoral white-collar jobs play key role in this process. The geography of the second global shift is strongly determined by the educational and language abilities of the service workers located in low cost locations (Bryson, 2007).Earlier routine tasks were relocated to low wage developing countries and more recently even the core, more skill-intensive core functions became offshorable even to new locations of the emerging countries. The second global shift in services offers benefits for countries at both ends of this process and participants can reap the benefits of the new global division of labour of this shift. The receiving countries gain jobs, technology, skills and access 


\author{
(online) $=$ ISSN $2285-3642$ \\ ISSN-L = 2285 - 3642 \\ Journal of Economic Development, Environment and People \\ Volume 2, Issue 3, 2013 \\ URL: http://jedep.spiruharet.ro \\ e-mail: office jedep@spiruharet.ro
}

to global markets, while the investor countries save cost and improve their competitiveness as they can move into the higher value added activities.

The driving forces behind the new wave of offshoring are not simply low wages, but the increased electronic tradability, lower capital intensity and sunk cost of service relocation, which make easier to transfer services to the wider varieties of locations across the globe. Another argument in the literature is that relocation of manufacturing during the first global shift is tended to be more geographically embedded as affiliates built stronger links to the local suppliers and local markets, while service relocation can be regarded as more footloose (Jones and Kierzkowsky, 1990; Arnt and Kierzkowsky, 2001).

Table 1: Offshoring is not a new phenomenon: First and a second global shift

\begin{tabular}{|l|l|}
\hline $\begin{array}{l}\text { First global shift } \\
\text { (relocation of manufacturing jobs) }\end{array}$ & $\begin{array}{l}\text { Second global shift } \\
\text { (relocation of service tasks) }\end{array}$ \\
\hline First wave in the 1980-90s & Since the Millennium: new wave \\
\hline Blue collar jobs & White-collar jobs \\
\hline Impacts by industry - manufacturing & Across sectors and across nations -service occupations \\
\hline Transportation enabled & Internet enabled \\
\hline Driven by wages & $\begin{array}{l}\text { Driven by wages, by new business concept, language, } \\
\text { technical training }\end{array}$ \\
\hline High capital investment required & Lower capital requirement (proceed faster) \\
\hline Limited to particular manufacturing sectors & Potentially affects firms in all sectors \\
\hline $\begin{array}{l}\text { Geographically more embedded: stronger links to local } \\
\text { suppliers }\end{array}$ & Geographically more footloose \\
\hline
\end{tabular}

Source: Edited by the author.

Although separating tasks alongside the entire value chain in time and space, (geographic) proximity as Hillberry and Hummels (2008) argue still matters a great deal for many tasks. While some tasks can be undertaken easily from a large distance, others require more face-to-face contact. It highly depends on the 


\author{
(online) = ISSN $2285-3642$ \\ ISSN-L = 2285-3642 \\ Journal of Economic Development, Environment and People \\ Volume 2, Issue 3, 2013 \\ URL: $\underline{\text { http://jedep.spiruharet.ro }}$ \\ e-mail: office jedep@spiruharet.ro
}

type of tasks (routine or non-routine) and their information content ${ }^{3}$. This resonates to Grote and Täube's (2007) argument in which proximity requirement selects between the different organizational and spatial forms of reorganization of value chains and it can be a selection tool between the core and non-core activities. The option of outsourcing certain stages of business tasks and offshoring part of the value chain abroad depends largely on the embeddedness of certain functions in relation to their internal corporate structure and to their corresponding locations abroad. They distinguish different kinds of proximities (spatial, organizational, cultural and professional) necessary for the transfer of information and knowledge in financial services ${ }^{4}$.

\title{
3. The international offshoring services market
}

There are a large number of consultancy reports on service offshoring and each provides rather different estimates of the size and its impact on employment. McKinsey's study finds that service providers have so far captured only 10 percent of a $\$ 300$ billion offshoring opportunity. Their analysis indicates that approximately 35 percent of the work that could potentially be offshored, worth $\$ 110-120$ billion and divided equally between IT services and business processes, actually will be offshored by 2010 (McKinsey, 2006.). The significance of offshoring is often overestimated and it is because still only smaller portions of services are relocated abroad. In fact, offshoring is by no means as important as one can expect from the rapid surge in FDI data and ongoing political debate on the job losses. ${ }^{5}$ Most outsourcing remains predominantly domestic affair and only a small share of service outsourcing is international. According to the IMF calculation based on trade data, the share of imported intermediate goods and services is about $10 \%$ of total import in the eight OECD countries selected by the study. Service offshoring is even more underdeveloped. The ratio of imported intermediates to gross outputs of industrial products rose from $6 \%$ to $10 \%$ between 1980 and 2003, whereas the ratio in services was still only $1 \%$ in 2003 . However the growth rate for offshoring intensity of services was much higher than in the industry $(8.4 \%$ to $1.3 \%$ since

\footnotetext{
${ }^{3}$ Leamer and Storper's (2001) theorem has a strong implication for offshoring as only those services can be relocated which are based on routine cognitive processes, have high information content, internet-enabled, require no face-toface contacts and easy to set-up even in remote locations and easy to manage cross-nationally. Nevertheless, most personal services cannot be performed from distance, while impersonal services even the core tasks of financial services are liable to offshoring.

${ }^{4}$ Grote and Täube's $(2006,2007)$ argue that outsourcing becomes an option only when organizational proximity is not necessary. When organizational proximity is needed, relocated units have to be fully owned subsidiaries. Moreover, the content of the processes to be outsourced ought not to be strategic to the outsourcing company. Offshoring of complex tasks is also possible for parts of the value chain that do not require cultural and spatial proximity and where professional proximity ensures sufficient common background for communication (Grote and Täube, 2006, 2007).

${ }^{5}$ The outsourcing market is close to 300billion USD of which only 80 billion USD is subject to offshoring (XMG Report, 2007).
} 


\author{
(online) = ISSN $2285-3642$ \\ ISSN-L = 2285-3642 \\ Journal of Economic Development, Environment and People \\ Volume 2, Issue 3, 2013 \\ URL: $\underline{\text { http://jedep.spiruharet.ro }}$ \\ e-mail: office jedep@spiruharet.ro
}

1990) such as the labour productivity generated by service offshoring (Amiti and Wei, 2005; Bräuninger, 2007).

Offshoring is a key driver of geographically re-engineering corporate value chains as re-location of certain service activities requires the geographical reorganization of firms' value chains by choosing among a number of locations. There is a number of factors at play, and these must be considered when drafting a successful offshoring strategy. Besides the lowest cost, other factors have to be taken into account such as hidden cost and the higher risks of the low cost environment that might drive the firms to select other more quality based locations. The "closer to home or closer to expansion" strategies are applied when TNCs prefer the establishment of sub-centres nearshore or close to the geographical direction of the future market expansion. Nearshoring just like offshoring is not a new phenomenon. Many US-based companies had been using the relatively lower cost employees of Canada and Ireland for many years until India and other very low-cost developing countries became the dominant players at global scale. Earlier each major industrial core had its own offshoring backyard located nearby. Nearshoring means sourcing service activities to a foreign, lower-wage country that is relatively close in distance or time zone and often within the same continent. The customer expects to benefit from one or more of the following constructs of proximity: geographic, temporal, cultural, linguistic, economic, political, or historical linkages ${ }^{6}$.

Nowadays, location strategies of companies in global sourcing shift towards the multiple sourcing strategy creating 'global footprints' in a form of hub and spoke model to spread risks among a number of locations, regions and the number of collaborating partners to create global quality labour pool and improve operational performance. Such a strategy creates an optimal mix of locations taking cost, labour pool, language, time zones, cultural factor and regional coverage into account These strategies may appear as alternatives but in most cases firms have developed a global delivery model based on "blended delivery systems" that "capitalise on the place-based advantages of coupling or blending activities located in a variety of different locations: home-near-far' (Bryson, 2007). . For larger TNCs it is more appropriate to cluster footprint with operations located in different regions in order to reduce their dependency on any single location.. The goal is to have in each geographic region either a regional or a country presence to serve local needs and a global hub to serve as a large-scale transaction engine for all work that is location

\footnotetext{
${ }^{6}$ There is a considerable heterogeneity referring to the actual meaning of "offshoring". It can be used simply to cover anything from 'outside of country boundaries' or 'not domestic or not a border country' to 'remote lower cost locations' or 'outside of the continent'. In a more widely used interpretation it refers to developing low cost countries that are located outside the First World (Jahns et al., 2006). The geographic dimension of service locations refers to onsite (on the premises of the focal company) and offsite (outside the premises but in the same country) together forming the onshore alternatives, as well as nearshore (relocation of services within a shorter distance, often in the same continent) and, finally, offshore or farshore (developing countries for e.g.US-based companies) options.
} 


\author{
(online) = ISSN $2285-3642$ \\ ISSN-L = $2285-3642$ \\ Journal of Economic Development, Environment and People \\ Volume 2, Issue 3, 2013 \\ URL: $\underline{\text { http://jedep.spiruharet.ro }}$ \\ e-mail: office jedep@spiruharet.ro
}

independent, and does not require territorial embeddness. In this context, different local territories are in competition as much as firms.

\title{
4. An emerging offshoring hub: Central and Eastern Europe
}

The following section explores the reasons behind the growing popularity of CEE as an offshore location, and besides consultancy reports examines the trade data to find evidence of offshoring related service intensity, and finally East European locations compared to other earlier established Asian locations, and discusses the sustainability of the region's attractiveness.

Even as most US and UK companies turn to India to relocate many of their service outsourcing jobs, over the last decade a growing number of outsourcing services seekers from Western Europe have found Bangalores in their own backyard; countries in the CEE region, particularly Czech Republic, Hungary, Poland, Romania, Bulgaria, Russia and Ukraine. With the advent of new generation of service offshoring major companies after targeting India, the Philippines and China as the prime destinations for offshoring technology and call-centre jobs, are now looking towards Eastern Europe to meet their nearshoring requirements.

What are the main driving factors behind the rise of the nearshoring destinations in CEE? First, it can be partly explained by the external factors, namely by the growth demand and new business strategy direction are encouraging more and more European companies to gain benefits of service offshoring. This demand met the increasing supply from the CEE countries wanting to benefit from the new wave of FDI shift to services and they are pitching themselves as ideal nearshore locations. Until the early 2000s offshoring was almost exclusively 'reserved' for the Anglo-Saxon world with limited opportunities for Japanese, French and German companies. As pooling services and offshoring has become part of the mainstream strategy, many of the European companies needed service centers that can operate in European languages. As Indian locations cannot support operation in other languages but English, therefore German, French and Scandinavian countries are looking to gain the benefits through relocation in nearshore East European locations. They require services in their own languages and tend to demand a higher degree of cultural embeddedness, especially in their customer facing activities.

Another driver of nearshore growth is the expansion of offshoring towards new types of services. Not only the list of offshoring functions has grown steadily embracing core competencies, human resource management, analytical work and more complex customer related services but these new higher-value functions require more interactions that only nearshoring operation can provide, namely language skills cultural understanding, same time zones and geographical proximity. 


\author{
(online) = ISSN $2285-3642$ \\ ISSN-L = 2285-3642 \\ Journal of Economic Development, Environment and People \\ Volume 2, Issue 3, 2013 \\ URL: $\underline{\text { http://jedep.spiruharet.ro }}$ \\ e-mail: office jedep@spiruharet.ro
}

The third driver of the nearshoring boom is the rise of global service delivery model, which creates a pool of global labour located in a large number of service centres around the globe in order to optimise global operation of service providers through their so-called global footprint strategy.

Offshoring can be regarded as a growth market that is gaining breadth and depth. The breath is measured by the number of new players from both the supply and demand sides that take share of this business, while depth is generated by the growing complexity of tasks offshored. Countries in Central and Eastern Europe are gaining importance as offshoring locations. In 2003 CEE with its 1Bn USD share in the global offshoring market is worth to $40 \mathrm{Bn}$ USD lagged far behind the more prominent locations, such as India, Ireland and the Philippines (McKinsey, 2006). The share of CEE is rapidly growing as in 2003 only 5\% of service related global FDI projects invested there, while in 2006 more the $22 \%$ of FDI project went to the region. ${ }^{7}$ A.T.Kearney (2007) consultancy firm created an index of the most attractive countries for offshoring based on costs (financial attractiveness), economic and political environment (business environment) and human resources (skills availability). As expected India came out on top and more countries from CEE were also in the top quarter. As the most advanced CEE countries catch up with their western neighbours, nearly all improved their absolute score, although lose ground while emerging locations move up ranking, the costs and other location advantages are beginning to erode. Once a regional champion, the Czech Republic heading CEE locations at 4th place globally (2004) - but that was 12 places down by 2007. Bulgaria replaced the Czech Republic as the only country from the CEE region in the top 10. Both Bulgaria and Romania experienced a big progress in their business environment improvement because of reforms preceding their EU accession. Slovakia and the Baltic states also jumped into a better position. The Czech Republic and Hungary dropped in this ranking because of rising wages and other costs resulting in newer contenders within CEE are outshining these earlier established locations. Despite the continued environment improvement in the most established nearshore locations, all fell in rankings in relative cost competitiveness.

Business process offshoring in the form of captives of TNCs and third party providers began to take off in Hungary, Czech Republic and Poland from 1998 driven primarily by the improving investment climate, the development of modern office markets and cheap labour supply. New locations, such as Slovakia,

\footnotetext{
${ }^{7}$ Survey by UNCTAD of over 1,800 export-oriented FDI projects in 2002 and 2003 not surprisingly revealed India with its $12 \%$ share to be the largest single recipient of projects such as call centres, shared service centres and IT services, with Asia as a whole being the largest regional hub with its $40 \%$ share. Western Europe was not far behind with the UK being the principal location in Europe and second only to India overall. Central and Eastern Europe accounted for only $5 \%$ of the global market. These data reveal that most export-oriented service projects are still concentrated into developed countries (51\%), although lower-cost locations are rapidly catching up. In the case of shared service centres, developing countries and CEE economies attracted 65\% of all export-oriented FDI service projects in 2002 2003 (World Investment Report, 2004).
} 


\author{
(online) = ISSN $2285-3642$ \\ ISSN-L = 2285-3642 \\ Journal of Economic Development, Environment and People \\ Volume 2, Issue 3, 2013 \\ URL: $\underline{\text { http://jedep.spiruharet.ro }}$ \\ e-mail: office jedep@spiruharet.ro
}

Romania, and Bulgaria have emerged since the Millennium8. Central and Eastern Europe is still an attractive supplier for the European corporations. During the first stage of service FDI investment captives in the form of service shared centres were the main service providers, and recently global and even Indian vendors are opening their new centres in CEE to serve their European clients. In the early 2007, DTZ survey recorded 183 BPO operations across CEE revealing that the three core countries of Poland, Czech Republic and Hungary account for $77 \%$ of total BPO in $\mathrm{CEE}^{9}$.

Considering the shortcomings in different statistical sources, the indecisive evidence of the consultancy reports and the lack of a commonly accepted definition of offshoring this paper uses trade data depicted from the Balance of Payment statistics. This gives a good approximation to identify the trends in those sections of service trade which can be regarded as offshorable and helps to identify the geographical directions of contemporary delocalization processes within the region, and also highlights the shifts in county level performances in attracting offshored services. Following the international methodology (OECD, 2004, WTO, UNCTAD, 2005, Amiti and Wei, 2004, Ghibutiu and Poladian, 2008) two service categories are suitable to approximate the size of trade in offshorable services. Information and computer technology (ICT) and other business services (OBS) or outsourcable business services (BPO) are the most inclusive categories that may be regarded as potentially offshorable services. ${ }^{10}$

The question is whether the data support the widely accepted view that new member states (NMS) increasingly affected by the relocation of offshorable services. The tradability revolution in services is resulted in a rapid surge of relocation service activities. The NMS of the EU have achieved enormous progress in modernizing their service industries and from the Millennium have witnessed a rapid shift towards services in FDI inflows. FDI plays an important role in offshoring, although it is more difficult to quantify it and the tradability of services is already more visible in the patterns of service trade in the case of the six new EU member states (NMS-6) included in this study. ${ }^{11}$ Trade in services expanding from a very low base amounting to 63 billion Euro export by 2007, which is almost 3 times higher than that of in 1996. The share of the NMS-6 in the global service export is still modest (2.8\%) illustrating the lower exports capabilities of the region although their growth rate is higher than the global or the EU-15 average. In absolute terms Poland, Czech Republic and Hungary are the leader in this field.

\footnotetext{
${ }^{8}$ In 2006 Romania attracted over $40 \%$ of total BPO projects in the regions, which was higher than the correspondent Polish figure.

${ }^{9}$ The shares by countries were the following: Poland (32\%), Czech Rep. (25.7\%), Hungary (18.5\%), Romania (12.5\%), Slovakia (5.4\%), and Bulgaria (5.4\%).

${ }^{10}$ As Ghibutiu and Poladian, 2008 pointed out, it is difficult to distinguish between offshorable and offshored service parts because not all service trade is related to offshoring and nor it is possible distinguish between the affiliated and unaffiliated trade in respectively.

${ }^{11}$ Bulgaria, Czech republic, Hungary, Poland, Romania, Slovakia
} 


\author{
(online) = ISSN $2285-3642$ \\ ISSN-L = 2285-3642 \\ Journal of Economic Development, Environment and People \\ Volume 2, Issue 3, 2013 \\ URL: $\underline{\text { http://jedep.spiruharet.ro }}$ \\ e-mail: office jedep@spiruharet.ro
}

When looking at the sectoral composition of service export the still comparatively lower share of other services (including relocation related business services) is striking and this means that traditional branches of services reflected the pattern of the economic transition.

It is widely accepted that services offshoring means the global sourcing of business and IT services from abroad therefore to find further evidence of offshoring related service development, export data on the so called "offshorable services", namely on the other business and ICT services can be collected for NMS-6. The share of offshorable services within total service export has been steadily growing from $16 \%$ to $24.2 \%$ between 1997 and $2007^{12}$. The total value of offshorable services was equal to 15.3 billion Euro in 2007 and within this aggregate the overwhelming dominance of business services (85\%) is striking. In absolute term Poland and Hungary are the largest traders following by the Czech Republic and Romania. The growth rate of offshorable service export increased the most dynamically within the service sector as a whole and Romania, Poland and Hungary experienced the highest growth rate between 2002 and 2007. Due to the rapid growth of offshorable services export over the period of 2002-2007, in combination with the slower expansion of imports the deficits decreased steadily and this resulted in development of net trade gains amounting to 800 million Euro in NMS-6. Hungary increased its net export earlier than others, Poland reduced their deficits more rapidly, and turning it to small surplus, while Romania achieved the highest surplus by 2007 ( 800 million) within the shortest period.

Service trade statistics are supportive to the preliminary assumption that offshoring generated an expanding exports in particular service categories and a large proportion of business services export in the NMS has been associated with offshoring (Ghibutiu and Poladian, 2008). However, it is obvious that not all this kind of trade provided by offshored services. These data do not show how much of the offshorable services export really provided by offshoring service units and do not distinguish between the different organisational forms of offshore outsourcing and captive offshoring at the same time.

Besides findings based on statistical evidence there are qualitative approaches to define the comparative advantages of CEE arises from the combination of geographical, organizational and cultural proximity to Western Europe. It can be argued that the attractiveness of CEE is based on talent and geography, rather than on low wages and vast labour pool Three groups of apparently important capabilities drive the nearshoring advantages of CEE.

First, these countries have close geographical, political and cultural ties with Western Europe that allows proficiency in clients' languages. The advantages of EU membership not only diminished the external

\footnotetext{
${ }^{12}$ On country level some offshorable export shares increased even more between 2002 and 2007: Hungary from 20\% to32, Romania from $24 \%$ to $30 \%$ and Poland from $13 \%$ to $21 \%$.
} 


\author{
(online) = ISSN $2285-3642$ \\ ISSN-L = 2285-3642 \\ Journal of Economic Development, Environment and People \\ Volume 2, Issue 3, 2013 \\ URL: $\underline{\text { http://jedep.spiruharet.ro }}$ \\ e-mail: office jedep@spiruharet.ro
}

risks but dramatically simplified the administration cost as well. CEE as a nearshoring location score high marks because of its lower cost for communication between the costumer and service provider. Nearshoring locations not only reduce costs and risks of working with distant foreign companies but also ease personal contacts. The sense of humor, the directness of communications and common cultural understandings has always been important cultural elements of successful interactions and a constant point of frustration when crossing cultural barriers. Besides close proximity that may improve the efficiency of day-to-day information exchange to a service provider allows companies to develop intimate working relations. Being in the same time zone is a huge advantage especially if projects require frequent travelling demands and also CEE is particularly interesting for companies who require voice and customer-facing services in their mother languages ${ }^{13}$ (Meyer, 2006).

Second, the comparative advantages of CEE still to a large extent lie in the wage differences as cost savings are still one of the most important motives for offshoring. In CEE, labour costs are much lower than in Western Europe, although it varies largely within the region. The salaries in the region are 40 to 60 percent lower than on the Western Europe continent. Hungary, the Czech Republic and Poland have the highest average salaries while; Romania and Slovak Republic have relatively lower average salary levels. While in the EU-8 labour costs for non-public services are around one quarters of those in Germany, the costs are in Romania and Bulgaria about $10 \%$ of those in Germany. Comparative advantages in wages between countries and regions can change relatively fast, although CEE will remain relatively cheap for the near future. Ultimately, no low-cost country can remain low-cost forever. Most of the CEE countries are not among the cheapest locations and outpace those of the low-cost Asian countries. As costs in the most advanced CEE countries converge towards EU levels, companies are moving farther East in their search for high-skill and low-cost solutions (Russia, Ukraine, and Turkey).

The third, much has been said about the quality of labour in the region which consists of highly educated, well-trained and motivated workforce, achieving high degree of productivity and flexibility. In total, CEE produces much lower number of university graduates than its large Asian counterparts. However, the CEE graduates turn out to be by far more suitable to work for TNCs. According to the McKinsey Global Institute's survey job candidates from CEE had higher suitability rate (around $50 \%$ on average, whereas $80 \%$ in developed countries) across all occupations than their Asian or Latin American counterparts (McKinsey 2005). While the technical universities have maintained their quality standard the

\footnotetext{
${ }^{13}$ In Eastern Europe, the share of German speaking graduates can be as high as the number of English speaking ones. (Nearly $40 \%$ of schoolchildren learn German while $70 \%$ of them English). Romania is particularly interesting destination for French companies as $85 \%$ of schoolchildren learn French there
} 


\author{
(online) $=$ ISSN $2285-3642$ \\ ISSN-L = 2285-3642 \\ Journal of Economic Development, Environment and People \\ Volume 2, Issue 3, 2013 \\ URL: $\underline{\text { http://jedep.spiruharet.ro }}$ \\ e-mail: office jedep@spiruharet.ro
}

share of science and engineering graduates is lower than Indian or West European averages, which in turn is diminishing the region's capability to specialize in IT or sciences-based service provision.

A few studies have tried to estimate the impact of Eastern European nearshoring locations on the global market breakdown and on the largest global players, such as India. India emerged as the "destination of choice" for offshore delivery of almost all kind of IT and business processes, when compared with other countries. India will remain the leader in global sourcing and CEE provides a much smaller scale pool of different factors facilitating service relocations.

\title{
5. Future Bangalores? New geographies of emerging offshoring locations in CEE
}

Offshoring can have benefits for the host market and generates changes within the service sector as a whole. It also can have the potentially positive effects on consumers of final services, and on producers using intermediate services in terms of better service provision and spillover effects. The following section examines the implications of offshoring for the home markets in CEE, and in particular assesses its impact on their locations and on the urban network.

What is the most likely impact of services offshoring on the home economies? GDP growth of nations largely depends on service innovation. Offshoring is a major driver of shift towards services in FDI. This gains a particular importance in the CEE countries after their EU accession as it helped to mitigate the fear of TNCs' outmigration in manufacturing and it substituted the decreasing share in manufacturing FDI by service investments. The relocation of service tasks results in additional export-oriented capacities in services and increased productivity which may result in spillovers to the local economy, thus accelerating growth and providing additional employment, higher wages and tax. FDI can spur local service providers to become more competitive through demonstration and skills diffusions, thus helping them improve efficiency and create their local brands in knowledge intensive business services. Offshoring enables the host countries to shift to higher value services (Sass, 2008).

Besides the general home market effect the process of selecting and opening new locations is similarly important as offshoring has a strong impact on the cities selected. A key reason to outsource is to save costs, and most discussions on cost revolve around the wages at outsourcing locations. This can be extremely misleading because it precludes several other operating costs - support staff salaries, cost impact of attrition, training, management costs and corporate overheads, real estate, communications and technology costs. These costs vary across cities, and can influence a company's decision to outsource there. There is little doubt that not purely the cost saving is the primary driver of location selection. As more firm recognising offshoring as a part of their longer-term strategies, other factors have to be taken into consideration. 


\author{
(online) $=$ ISSN $2285-3642$ \\ ISSN-L = 2285 - 3642 \\ Journal of Economic Development, Environment and People \\ Volume 2, Issue 3, 2013 \\ URL: http://jedep.spiruharet.ro \\ e-mail: office jedep@spiruharet.ro
}

Location strategy making is a multi-faceted process, with different indicators coming into play as the focus is narrowed from macro-regions to countries, cities, district and finally individual property level. However choosing a suitable location is not just a matter of selecting the right country. Nevertheless, companies searching for locations should first focus on defining their priorities in terms of countries (cost, skills, business environment, and proximity) before ranking their specific locations. Country versus city approach is heavily dependent on the selection criteria and equally important to distinguish between some county and city-centric parameters of location sourcing classified. Legal system and business environment are more or less the same for all the cities in a country, the availability of raw manpower, infrastructure and risk are moderately similar within a country, while availability of university graduates, labour and real estate costs and maturity of the ecosystem in a particular offshoring location can be very different within a country. Employment costs differ widely among cities because of limited labour mobility and varying unemployment rates. Companies need to spend time to scrutinise the attractiveness of cities. They must consider various elements of cost, not just salaries and the specific skill sets that each city can provide. Locations that meet requirements for resource availability, quality, operational flexibility and economics stand to become preferred destinations. In choosing a city, companies need to focus less on low wages and more on other ways that candidate cities can fulfil their business needs.

Offshoring has also given a new spur in metropolitan development as the EU expanded eastwards. The subsequent stages of systemic transformation, global transformation characterised by the reintegration of the Central European capital cities into the world-city network. Three capital cities (Budapest, Prague, and Warsaw) entered in the 1990s successfully into the world city system with fully-fledged gateway functions. The metropolitan transformation accompanied by both the rapid deindustrialisation and expansion of services has resulted in the concentration of the high-level business and financial services into the capital cities (Lux, 2010). Simultaneously interactions and symbiotic competition emerged between the capital cities, as they have been competing for attracting investments and have aspiration for business centre function with significant international scope. EU accession, competitive infrastructure costs and strong education system as favourable preconditions supported the first group of capital cities, such as Prague, Budapest and Warsaw in the first wave of the offshoring boom, and they recently followed by Bucharest and Sofia due to the saturation of the former capitals (see Figure 2). These cities were the most successful to reposition themselves during the early stages of transition by exploiting their comparative advantages on global market place. At the beginning costs (labour cost, real estate prices and facilities) were the most important driver in selecting these location mostly for routine offshoring activities. However, these capitals have relatively higher wages comparing to their Asian and Latin American counterparts, which due to the EU accession resulted in further growth in labour costs. Nevertheless, cost differential with Western Europe are still significant, making these cities still attractive for higher value added nearshore service activities. 


\author{
(online) = ISSN $2285-3642$ \\ ISSN-L = $2285-3642$ \\ Journal of Economic Development, Environment and People \\ Volume 2, Issue 3, 2013 \\ URL: $\underline{\text { http://jedep.spiruharet.ro }}$ \\ e-mail: office jedep@spiruharet.ro
}

The list of the Top 50 outsourcing cities worldwide based on the Tholons consultancy survey (2007) includes 13 cities from CEE, although only Kraków and Brno are not capitals. Bucharest, Sofia, Kiev, Tallin and Moscow have already established locations in the eastern fringe of the region. The first wave of cities in the offshoring boom, including the first tier capital cities such as Warsaw, Prague and Budapest are saturating in terms of skilled labour and offices supply, to the point that raises the opportunity for the second tier cities within and capital cities in other countries. As seen, companies initially located in the first tier capital cities, pushing up costs and attrition rates as direct consequences of market saturation. As a result, companies are constantly searching for new locations. The growing demand for new offshoring locations, as the more mature destinations saturated, gives an opportunity for governments and their investment agencies to attract further services FDI and create high-valued jobs with the introduction of few policy changes. In terms of BPO labour costs, especially Warsaw and lesser extent Budapest and Prague proved to be the most expensive locations.

Eastern European nations boast of numerous mid-size cities with little or no offshoring work is being done currently, but possess large talent pools and low labour costs that can be capitalized. ${ }^{14}$ Numerous cities particularly in Poland, Czech Republic and Romania are emerging as new destinations for outsourcing (see Fig. 2). Central and Eastern Europe are emerging as popular destination for Finance \& Accounting offshoring for the European market, the frontrunner being Krakow, Poland. There are approximately 30,000 graduates in Krakow, of which about 21,000 are graduates in economics. Capgemini has its largest F\&A and R\&D offshoring centre in Krakow. Some of the other cities in the CEE that are prime locations for F\&A outsourcing are Bratislava, Prague, Budapest and Bucharest. Accenture, Hewitt, IBM, Diageo and others have their European services centres in these CEE cities. Diageo, the world's leading premium drink business, located its business services centre in Budapest in 2001. Now, the centre employs about 500 people and performs financial and administrative tasks for 13 European Diageo business units.

${ }^{14}$ In Central Europe according to the survey conducted by the McKinsey Global Institute, beyond the already established locations there are 40-50 provincial cities with universities appropriate to supply a highly skilled labour. Interviews indicate that, in general, university graduates from Eastern European countries are, on average, well-suited to work for multinational companies. 


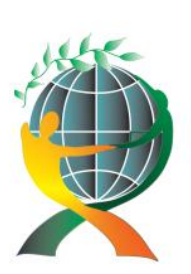

\author{
(online) $=$ ISSN $2285-3642$ \\ ISSN-L = 2285 - 3642 \\ Journal of Economic Development, Environment and People \\ Volume 2, Issue 3, 2013
}

URL: http://jedep.spiruharet.ro

e-mail: office jedep@spiruharet.ro

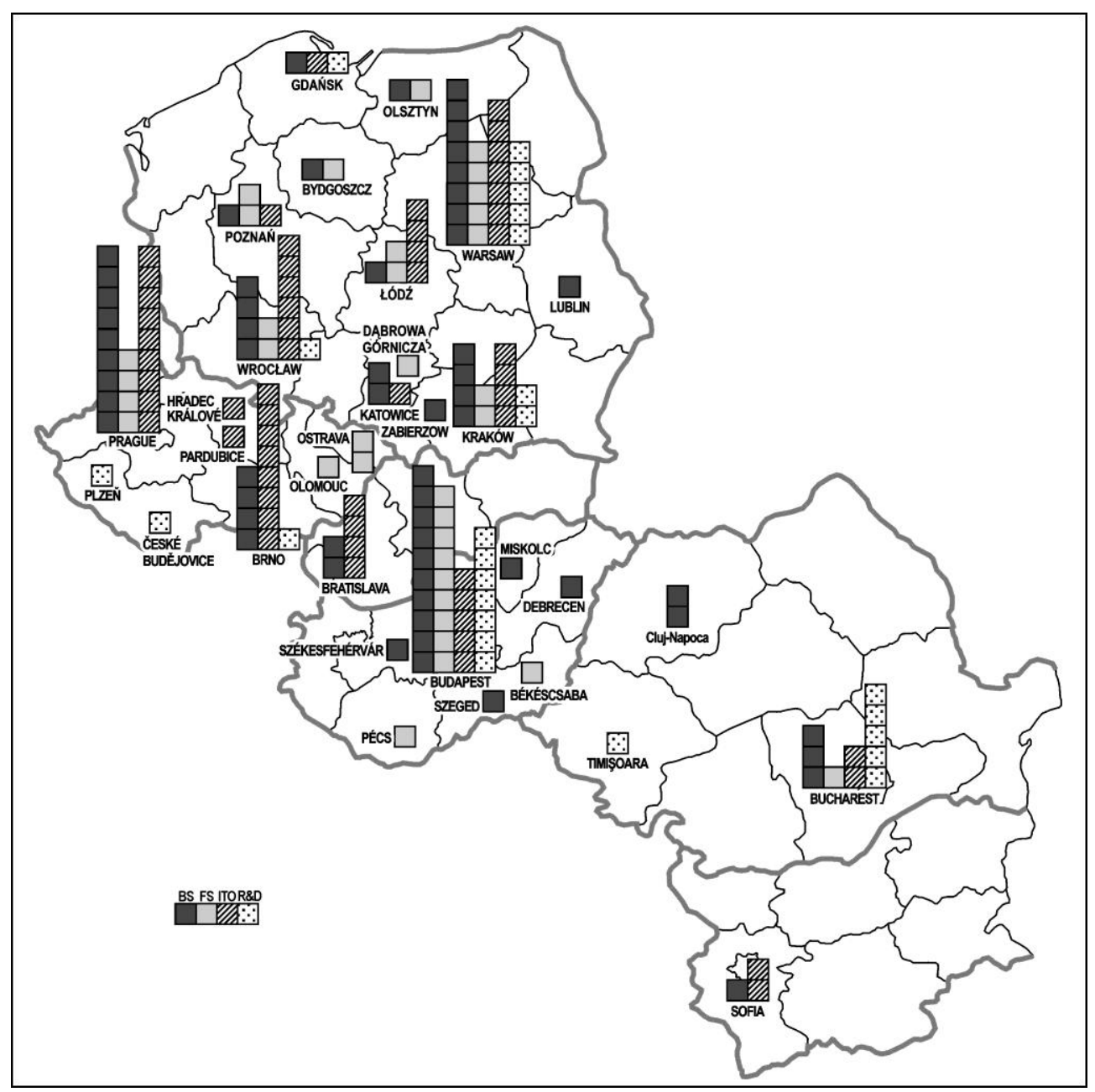

Fig. 2: Geographical and sectoral breakdown of the major services offshoring sites in Central and Eastern Europe, 2007 Legend: BS=business services; FS= financial services; ITO=Information Technology Outsourcing; R\&D=Research and development, Knowledge process outsourcing; One box is equal with one offshoring site.

Source: drawn by the author based on data of PAlilZ, Czehinvest and ITD-Hungary.

Poland, with the largest potential supply of skilled labour and the availability of untapped provincial locations has developed the most extensive network of offshoring locations. Poland has not only larger labour force (with nearly half a million graduates annually) but has more urban centres that can support large-scale operations and longer-term prospect, more so than any other countries in the region ${ }^{15}$. Besides Warsaw, Wroclaw and Kraków the already established hotspots, Lódz, Poznan, Katowice and Gdansk are among the emerging ones. While second tier Polish cities have been attracting BPO investments from the

\footnotetext{
${ }^{15}$ Labour supply can be tightened in provincial Poland too as cities in regional Poland in particular, have seen large flux of emigration to the Bristish Isles.
} 


\author{
(online) = ISSN $2285-3642$ \\ ISSN-L = 2285-3642 \\ Journal of Economic Development, Environment and People \\ Volume 2, Issue 3, 2013 \\ URL: $\underline{\text { http://jedep.spiruharet.ro }}$ \\ e-mail: office jedep@spiruharet.ro
}

late 1990s, BPO work has only recently found its way to the provincial locations in the Czech Republic. Cheaper regional university centres such as Pardubice, Hradec Kralove and Ostrava with higher unemployment and ready supply of lower cost graduates started to attract cost-conscious call centres migrating out of Prague. Brno succeeded to establish its own location brand even for core services.

However, Hungary once a forerunner in the establishment of shared service centres and BPO opening its first location in 1999 has lost its leading position. Contrary to Poland, most of the projects have concentrated into the capital city of Budapest and governmental agency failed to channel most of new investments towards the midsize cities. While BPO investment has been selected by the Polish and Czech agencies as a priority, the Hungarian agency however received criticism concerning its marketing activity. Not only nations but cities also have an opportunity to promote their location. Lódz, in Poland, among others, has undertaken such an investor promoter initiative, which has been helping to make the city a booming BPO hub. Deloitte's Global location Survey examined Hungary's untapped offshoring locations and selected 5 provincial cities (Debrecen, Kecskemét, Pécs, Székesfehérvár, and Szeged) which should be considered as so-called "under the radar" locations offering an attractive cost/quality ratio that can stand comparison with Budapest. As in other spheres of economic activity in Hungary Budapest dominates the BPO and ITO sectors. Hungary has no suitable office market in its midsize cities. Companies do investigate provincial locations but invariably return to Budapest due to the lack of suitable offices. Alternative options to the costly Budapest tend to be crossborder, such as Bucharest or even Kyiv rather than Miskolc, Pécs or Debrecen. Most of the few provincial BPO locations are located nearby the eastern borders of Hungary taking the operators' intention for their future cross border expansion and easier labour hire into account ${ }^{16}$.

In high-demand countries such as the Czech Republic, Poland and in a smaller scale in Hungary many outsourcing vendors are setting up smaller centres with less than 500 employees to avoid the risk associated with the maintenance of a large workforce. Additionally, smaller workforces are more aligned to the smaller labour supply in tier-2 cities, which has the added benefits of lower labour and facilities costs that can more than offset any benefits of scale in capital cities. More Vendors maintain operations in both the capital city and secondary cities in Hungary. Budapest is leveraged for higher-value work, while lower level processing is accomplished in secondary locations that offer much lower costs and extremely lower attrition sites.

Cities with the right combination of location factors will be the winners in the future waves of BPO investment into CEE. Certain locations suffer from structural problems such as low labour supply, higher

\footnotetext{
${ }^{16}$ The under-development of certain eastern regions of CEE lacking of regional airports, motorways and international schools can deter expatriate manager staff of BPO operations to locate there. In terms of office market the smaller secondary locations can be difficult to beat the advantages of the capital cities or the larger regional centres (Brno, Kraków, Wroclaw).
} 


\author{
(online) $=$ ISSN $2285-3642$ \\ ISSN-L = 2285-3642 \\ Journal of Economic Development, Environment and People \\ Volume 2, Issue 3, 2013 \\ URL: $\underline{\text { http://jedep.spiruharet.ro }}$ \\ e-mail: office jedep@spiruharet.ro
}

wages, lack of suitable office space or weaker language and technical skills, but BPO is more likely to choose another CEE location rather than leave the entire region. The challenge for individual cities will be to build their attractiveness and competitiveness by investing into their ITC infrastructure, education and business environment.

\title{
6. Conclusion
}

Offshoring is not a new phenomenon as it has historical roots. What is new now is not only its application to knowledge intensive business services shaped by technology allowing far more tasks to be offshored. Offshoring is also a key driver of geographically re-engineering corporate value chains by selecting among a number of operation management techniques and location strategies. As seen, offshoring also became a key globalisation force, and one can argue it is the latest stage of globalisation. Offshoring, partly because of its strong geographical implication has not only been challenging the traditional division of territorial labour, but it has been also a stimulus to develop new macroeconomic models.

As more and more companies recognise the advantages of offshoring, the practice will likely take hold in Western Europe, albeit more slowly than it did in the USA and the UK. Moreover, language sensitive, less experienced and smaller Western European firms tend to choose nearshoring locations in CEE at the first instance. Due to its geographical and cultural proximity, set-up costs are lower, and monitoring can be carried out more intensively than in the case of distant offshoring locations. Despite its popularity among offshoring, destinations Central European countries cannot effectively challenge positions of the earlier established locations, such as India, and particularly cannot compete with it in volumes and IT specialisation. More established locations in CEE also functions as a stepping-stone for eastward expansion and subsequent offshoring locations generating competition within the region.

Central and Eastern Europe offers five primary advantages in which its Asian competitors cannot compete: cultural and geographical proximity to Western Europe, still competitive wages (especially if one can consider India's wage inflation), good educational standards reflected by the higher rate of graduates' suitability, low risk profile and reliable infrastructure. "What is unusual about Eastern and Central Europe is that their most advanced cities offer a potent mix of attributes that even Bangalore cannot rival: a highly educated, multilingual pool of talent in an increasingly affluent consumer market - all barely a stone's throw from its prime clients" (The New York Times, 30 April 2007).

Building on these factors CEE is likely to utilize more value added quality-driven services. The shift from non-core (call-centre) to core business process activities (accounting, research \& development, transaction processing, customer relations, solution creating services) reinforces the region's comparative advantages. Financial institutions with already existing businesses in CEECs can explore the opportunities of 


\author{
(online) = ISSN $2285-3642$ \\ ISSN-L = $2285-3642$ \\ Journal of Economic Development, Environment and People \\ Volume 2, Issue 3, 2013 \\ URL: $\underline{\text { http://jedep.spiruharet.ro }}$ \\ e-mail: office jedep@spiruharet.ro
}

centralising their regional operations in these locations (as an alternative to SSCs in more expensive Western Europe) in order to justify easier the goodwill from the public.

Central and Eastern Europe also takes advantage on the trend supported by the global service delivery models reducing dependency on any single location (India). The expansion towards the second and third tier city locations also gives further potential for offshoring expansion beyond the saturated and more expensive locations of the capital cities.

The question can be raised whether competitiveness can sustain for a longer-term by proximity of CEE to its customers. In fact, offshoring success is somewhat a temporary phenomenon. Comparative advantages currently enjoyed by an offshore destination may not predict for the future. Wages tend to rise as countries climb up the development ladder, which erode the very reason for offshoring. Further growth may be influenced by worsening macro-conditions of the host economies and future prospect of the region depends largely on government incentives and on the success of exploiting talent pools offered by provincial cities.

\title{
7. References
}

[1] Amiti, M. And Wei, S. Fear of Outsourcing. Is It Justified?" Economic Policy, 2005. April

[2] Amiti, M. And Wei, S. Services Offshoring, Productivity, And Employment. Evidence From The United States. IMF Working Paper. 2005. No. 05/238.

[3] Arndt, S. And Kierzkowski, H. (Eds.). Fragmentation - New Production Patterns In The World Economy, Oxford University Press, 2001. Oxford-New York.

[4] Bhagwati, J, Panagariya, A. And Srinivasan, T. N. The Muddles. Over Outsourcing, The Journal Of Economic Perspectives. 2004. Vol. 18. No. 4. Pp. 93-114.

[5] Baldwin , R. And Krugman, P. "Agglomeration, Integration And Tax Harmonization," European Economic Review. 2004. Vol. 48, 1, Pp 1-23, 2004.

[6] Baldwin, R. 2006. Globalisation. The Great UnbundlingS, Chapter 1, In Globalisation Challenges For Europe, Secretariat Of The Economic Council, Finnish Prime Minister's Office, Helsinki, 2006.

[7] Baldwin , R. And Robert-Nicoud, F. Offshoring. General Equilibrium Effects On Wages, Production And Trade, CEP Discussion Paper, 2007. No 794. May. 2007

[8] Blinder. A. Offshoring. The Next Industrial Revolution?, Foreign Affairs, March/April, 2006. Vol. 85 2, Pp. 113-128

[9] Bräuninger, D. Globalisation And Distribution - Industrial Countries Also Face The Challenge, Deutsche Bank Research, 2007. November 21, P.34

[10] Bryson, J. The Second Global Shift. The Offshoring Or Global Sourcing Of Corporate Services And The Rise Of Distanciated Emotional Labour, Geographiska Annaler, Series B. Human Geography, 89b, 2007. Suppl 1, 31-43

[11] Cuoto, V., Mani,M. And Lewin, A. The Globalization of White-Collar Work. The Facts And Fallout Of NextGeneration Offshoring, Booz Allen Hamilton And Duke University, 2007, April 13, 2007

[12] Dicken, P. Global Shift. Reshaping The Global Economic Map In The 21st Century, The Guilford Press, 2003, New York, London. 


\author{
(online) = ISSN $2285-3642$ \\ ISSN-L = $2285-3642$ \\ Journal of Economic Development, Environment and People \\ Volume 2, Issue 3, 2013 \\ URL: http://jedep.spiruharet.ro \\ e-mail: office jedep@spiruharet.ro
}

[13] Execution Is Everything. The Keys To Offshore Success, A Report From The A.T. Kearney Global Services. Location Index ${ }^{T M}, 2007$

[14] Friedman, T. The World Is Flat. A Brief History Of The Twenty-First Century, Pinguin Books, 2005, London.

[15] Gál Z._Future Bangalores? The Increasing Role Of Central And Eastern Europe In The Global Services Offshoring Market. Evidence From Trade Statistics. 2011. This Item Is In The Repository With The Url Http.//Mpra.Ub.UniMuenchen.De/28360/

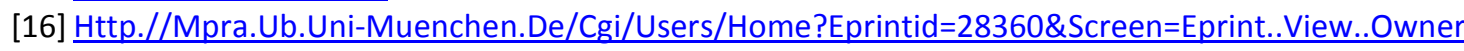

[17] Gál, Z, Sass, M. Emerging New Locations Of Business Services. Offshoring In Central And Eastern Europe. Regions Magazine, 2009, 274.1 18-22.

[18] Ghibutiu, A., Dumitriu, I. The Effects Of Offshoring On Trade In Services. Evidence From Romania, The European Trade Study Group, WTSG Working Paper. Available Http.//Www.Etsg.Org/Etsg Web/Etsg Site/Papers List.Php. 2008,

[19] Ghibutiu, A., Poladian, S. Global Sourcing And The New Member States. Seizing The Growth Opportunities And Facing The Challenges Reser, 2009,

[20] G.M. Grossman \& E. Rossi-Hansberg, Trading Tasks: A Simple Theory of Offshoring," American Economic Review, 2008.vol. 98(5), pages 1978-97, December.

[21] Grossman, G. And Rossi-Hansberg, E. The Rise Of Offshoring. It's Not Wine For Cloth Anymore. The New Economic Geography. Effects And Policy Implications, Federal Reserve Bank Of Kansas City, Jackson Hole Symposium, 2007.

[22] Grote, Michael H. And Täube, Florian A. Offshoring The Financial Services Industry. Implications For The Evolution Of Indian It Clusters, Environment And Planning A. 2006. Vol. 38, S. 1287-1305

[23] Grote, Michael H. And Täube, Florian A. When Outsourcing Is Not An Option. International Relocation Of Investment Bank's Research, Journal Of International Management. 2007. Vol. 131, S. Pp. 57-77

[24] Hillberry, Russell And Hummels, David, "Trade Responses To Geographic Frictions. A Decomposition Using MicroData," European Economic Review, 2008. Vol. 523, Pages 527-550, April.

[25] Jahns, C., Hatmann, E. And Bals, L., Offshoring. Dimensions And Diffusion Of A New Business Concept, Journal Of Purchasing And Supply Chain Management, 2006. Vol. 12, Pp. 218-231

[26] Jones, R. W. And Kierzkowski, H. 1990, 2005. The Role Of Services In Production And International Trade. A Theoretical Framework, In Rodney F. And Kreickemeier, U. Eds., Recent Developments In International Trade Theory, Issue, Pp. 308-348. Edward Elgar, 2005

[27] Jones, R. W. And Kierzkowski, H. A Framework For Fragmentation, Tinbergen Institute Discussion Paper 2000. 056/2.

[28] Leamer, E. And Storper, M. The Economic Geography Of The Internet Age, Journal Of International Business Studies, 2001. Pp.641-665

[29] Lewin, A., And Peeters, C., Offshoring Work. Business Hype Or The Onset Of Fundamental Transformation? , Long Range Planning, 2006. Vol. 39 221-239.

[30] Lux, G. The Service-Based Strategy Of Industrial Restructuring. A Szolgáltatásfejlesztés Mint Ipari Válságkezelési Stratégia, Gulyás, L. - Gál, J. - Baló, T. Eds Európai Kihívások European Challenges/v. Nemzetközi Tudományos Konferencia. Szegedi Tudományegyetem University Of Szeged, Mérnöki Kar, Szeged, 511-515. 2007.

[31] Lux G _Location Differences Of Services And Industry. A Central European Dichotomy. Prace Komisji Geografii Przemyslu Polskiego Towarzystwa Geograficznego, 2010, 16. Pp. 29-37.

[32] Mankiw, G. And Swagel, P. The Politics And Economics Of Offshore Outsourcing, With Phillip L. Swagel, Journal Of Monetary Economics, 2006. 53 5, July, 1027-1056. 


\author{
(online) = ISSN $2285-3642$ \\ ISSN-L = $2285-3642$ \\ Journal of Economic Development, Environment and People \\ Volume 2, Issue 3, 2013 \\ URL: http://jedep.spiruharet.ro \\ e-mail: office jedep@spiruharet.ro
}

[33] Metters, R. And Verma, R. History Of Offshoring Knowledge Services, Journal Of Operations Management, 2008. Vol. 262, Pp.141-147.

[34] Meyer T. Offshoring To New Shores. Nearshoring To Central And Eastern Europe, Deutsche Bank Research, 2006.August 14. P. 12

[35] Meyer T. Offshoring Work, Not Jobs. Deutsche Bank Research, April 12. P. 12 Economics, 2007. No. 61.

[36] Meyer, Thomas Offshoring Deos Not Explain Job Cuts At European Banks, Deutsche Bank Research, 2008. August. P.4.

[37] Offshoring. Is It A Win-Win Game? A Report From The Mckinsey Global Institute Mgi, 2003.

[38] Offshoring Of Services. Impact And Implications, International Finalcial Services London Research, March 2005.

[39] Outsourcing In Financial Services, The Joint Forum, Bank For International Settlements, August 2004.

[40] Outsourcing In Poland Challnges, Trends, Case Studies, A Report From The Conference Board And Accenture, 2006.

[41] Poland - Europe's Service Center?, New Foreign Direct Investment Opportunities In Poland, Mckinsey\&Company, Warsaw, 2003.

[42] Ricardo, D. On The Principles Of Political Economy And Taxation. London. 1817.

[43] Robert-Nicoud, F. Offshoring Of Routine Tasks And Deindustrialisation. Threat Or Opportunity -And For Whom?. Journal Of Urban Economics, 2008. 632, Pp. 517-35 March 2008.

[44] Robinson, M. And Kalakota, R. Pioneering Captive Centers - Excerpt From Offshore. Outsourcing. Business Models, Roi And Best Practices, Mivar Press, 2004.

[45] Sass, M. A Szolgáltatások Relokációja - Európai Folyamatok [Relocation Of Services - European Processes]. Európai Tükör, 2008. Xiii. Évf. 7.-8. Szám, 85.-100. O.

[46] Sass, M. , Fifikova, M. Offshoring And Outsourcing Business Services To Central And Eastern Europe. Some Empirical And Conceptual Considerations, European Planning Studies. 2011. Vol. 19. No. 9. , Pp. 1593-1609.

[47] The Emerging Global Labor Market.. Part li-The Supply Of Offshore Talent In Services. A Report From The Mckinsey Global Institute Mgi, June 2005

[48] The New Face Of Offshoring. Closer To Home?, A Report From The Economist Intelligence Unit. Sponsored By Hewlett-Packard, May 2006.

[49] The Rise Of Nearshoring - Outsourcing In Eastern Europe, Special Report, Economist, December $3^{\text {rd }} 2005$

[50] The Titans Take Hold, How Offshoring Has Changed The Competitive Dynamic For Global Financial Services Institutions, Deloitte Research Report, 2005.

[51] The Untapped Market For Offshore Services, A Report From The Mckinsey Global Institute 2006. May

[52] UNCTAD, 2004, World Investment Report 2004. Shift towards services, United Nations, Geneva 